\title{
Bioavailable Trace Elements in Soils around Nnpc Oil Depot Jos, Nigeria.
}

\author{
Babatunde O. A. ${ }^{1}$; A. O. Oyewale ${ }^{2}$ And Steve P. I. ${ }^{1}$ \\ 1. Department Of Chemistry, Nigerian Defence Academy Kaduna, Nigeria. \\ 2. Department Of Chemistry, Ahmadu Bello University, Zaria.
}

\begin{abstract}
The concentrations of trace elements $(\mathrm{Cu}, \mathrm{Zn}, \mathrm{Cr}, \mathrm{Pb}$ and $\mathrm{Cd})$ in soil samples around NNPC Oil Depot Jos and those of a control area (about a kilometer away from the depot) were investigated by sequential extraction method using Atomic Absorption Spectrometer (AAS). Results obtained showed the concentrations $(\mathrm{mg} / \mathrm{kg})$ of $\mathrm{Cu}, \mathrm{Zn}, \mathrm{Cr}, \mathrm{Pb}$ and $\mathrm{Cd}$ in soil of study area as 22.14, 25.06, 12.41, 14.13 and 9.11 respectively while in control area soil $\mathrm{Cu}, \mathrm{Zn}, \mathrm{Cr}, \mathrm{Pb}$ and $\mathrm{Cd}$ had concentrations (mg/kg) of 19.69, 22.79, 7.09, 13.53 and 1.24 respectively. The bioavailable components (obtained from exchangeable, water and acid-soluble, and reducible phases) of $\mathrm{Cu}, \mathrm{Zn}, \mathrm{Cr}, \mathrm{Pb}$ and $\mathrm{Cd}$ were $48.19 \%, 47.61 \%, 37.87 \%, 43.52 \%$ and $50.71 \%$ of their total concentrations respectively in study area soil while in control area $40.49 \%, 45.37 \%, 64.03 \%, 36.07 \%$ and $45.02 \%$ were obtained for $\mathrm{Cu}, \mathrm{Zn}, \mathrm{Cr}, \mathrm{Pb}$ and $\mathrm{Cd}$ respectively. Levels of the trace elements in soils of both study area and control area were observed to be within European Union safe limits except for Cd in the study area. Keywords: Bioavailable fraction, Oil depot, Pollution, Sequential extraction, Trace elements.
\end{abstract}

\section{Introduction}

Pollution is the introduction of contaminants into an environment that causes instability, disorder, harm or discomfort to the ecosystem i.e. physical systems or living organisms. The elements of pollution, otherwise known as pollutants can be foreign substances or energies such as noise, heat or light. They are considered pollutants when they exceed natural levels [1]. Contamination of heavy metals in the environment has been shown to be of major concern because of their toxicity and threat to human life and the environment. Several studies have been carried out on trace elements contamination in soils from various anthropogenic sources such as industrial wastes $[2,3,4,5,6,7$, and 8$]$.

Contaminants are mostly introduced into the environment by the activities of man. Most of these contaminants result from wastes generated by industries and residences and are disposed of on land and in water bodies without proper treatment [9].

Depending on their origin, trace elements exist in different mineral forms and chemical compounds and in different combinations with mineral and organic components of soil and sediments which may vary according to various conditions. For instance, $\mathrm{pH}$ has an influence on trace element forms, other parameters affecting their concentration levels, mobility, transformation and accumulation processes in the ecosystem are redox conditions, oxidation states, temperature, the presence of organic matter and microbiological activity. All these factors influence the biogeochemical cycles of elements in our environment [10]. All trace metal hydroxide, oxide, carbonate and phosphate precipitates form only under alkaline conditions [11]. The dissolution of these metal precipitates is strongly dependent on the $\mathrm{pH}$ of the system. In acidic soils, simple cations and complexes of chlorides and sulphates usually exist, while in neutral and slightly alkaline conditions carbonate complexes dominate [12].

Total metal concentrations do not necessarily correspond with metal bioavailability [13 and 14]. For example, sulfide minerals may be encapsulated in quartz or other chemically inert minerals, and despite high total concentrations of metals in sediment and soil containing these minerals, metals are not readily available for incorporation in the biota; associated environmental effects may be low [15]. Metals of major interest in bioavailability studies, as listed by the U.S. Environmental Protection Agency (EPA) are $\mathrm{Al}, \mathrm{As}, \mathrm{Be}, \mathrm{Cd}, \mathrm{Cr}, \mathrm{Cu}$, $\mathrm{Hg}, \mathrm{Ni}, \mathrm{Zn}, \mathrm{Pb}, \mathrm{Se}$, and $\mathrm{Sb}[16]$.

An oil depot (sometimes called a tank farm, installation or oil terminal) is an industrial facility for the storage of oil and/or petrochemical products and from which these products are usually transported to end users or further storage facility. Oil depots are usually situated close to oil refineries or in locations where marine tankers containing products can discharge their cargo. Some depots are attached to pipelines from which they draw their supplies [1]. Pipelines traversing the nooks and crannies of Nigeria have been reported by NUPENG to be vandalized and some ruptured due to old age, and that some of the NNPC depots nationwide are not operational but are crying for attention from the Federal Government [17].

This research was to determine the presence of bioavailable trace elements (i.e. $\mathrm{Cu}, \mathrm{Pb}, \mathrm{Cr}, \mathrm{Cd}$, and $\mathrm{Zn}$ ) in soils around NNPC oil depot Jos and to compare result obtained with those of a control area (about $1 \mathrm{Km}$ 
away from the depot). Also, results obtained were to be compared to prescribed levels by the European Union standard [18] for the elements in soils.

\section{Materials And Methods}

Analytical (AnalaR) grade reagents and distilled water were used for the experiment. All glassware and plastic containers used were washed with liquid soap, rinsed with water, soaked in 10\% (v/v) nitric acid for 24 hrs, cleaned thoroughly with distilled water and dried.

\section{SAMPLING SITE}

The samples were collected around the Jos NNPC Oil Depot, situated along Zaria road, Jos (longitude $8^{\circ} 54^{\prime}$ and latitude $\left.9^{\circ} 55^{\prime}\right)$. The sampling sites are indicated in Fig. 1.

Hampling sites

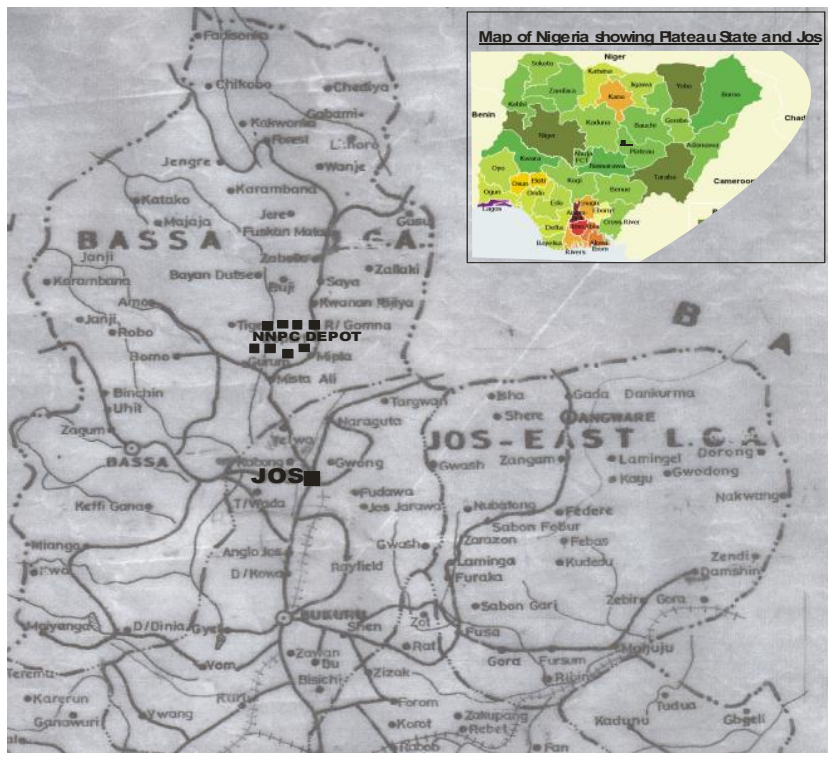

Fig: 3.1 Map of Jos environs showing NNPC Depot

\section{SAMPLE COLLECTION}

Soil samples ( 3 samples each per site) were collected at a depth of 0-30 cm using stainless steel spoon from ten (10) different points 50 metres away from the oil depot. The distance from one sampling point to the other was about 10 metres.

Control soil samples (3 samples each per site) were collected from six (6) different points of control area at a distance of about $1 \mathrm{Km}$ away from the oil depot. A polythene bag was used for the storage of the samples.

Composite samples were prepared for soil samples by combining together the triplicate (3) samples collected from each site.

\section{SAMPLE TREATMENT AND PRESERVATION}

Soil samples were sieved using $2 \mathrm{~mm}$ sieve to remove stones and plant fragments, dried at $105^{\circ} \mathrm{C}$ in an oven and crushed into fine powder using an agate mortar.

\section{SAMPLE PREPARATION (DIGESTION)}

Sequential extraction procedure proposed by the Standard Measurements and Testing Programme (SM\&T- formerly Community Bureau of Reference) of the European Union, as reported in similar study [12] was employed to analyze for the trace elements in soil.

i. Exchangeable metals (Fraction I): $40 \mathrm{~cm}^{3}$ of $0.11 \mathrm{~mol} \mathrm{dm}^{-3}$ acetic acid was added to $1.00 \mathrm{~g}$ of dry soil sample in a $50 \mathrm{~cm}^{3}$ polypropylene tube. The mixture was shaken $(400 \mathrm{rpm})$ using a Clifton shaker for $16 \mathrm{~h}$ at room temperature. The extract was separated from the solid phase by centrifugation at $3800 \mathrm{rpm}$ for $20 \mathrm{~min}$. The supernatant liquid was decanted into a $100 \mathrm{~cm}^{3}$ beaker and then covered with a watch-glass. The residue was washed by adding $20 \mathrm{~cm}^{3}$ of deionized water, shaking for $15 \mathrm{~min}$, and then centrifuging. The second supernatant liquid was discarded without any loss of residue.

ii. Metals bound to Iron and Manganese oxides (Fraction II): Metals bound to iron and manganese oxides were extracted by adding $40 \mathrm{~cm}^{3}$ of $0.1 \mathrm{~mol} \mathrm{dm}$ hydroxylammonium chloride (adjusted to $\mathrm{pH} 2.0$ with $2 \mathrm{~mol} \mathrm{dm}^{-}$ 
${ }^{3}$ nitric acid) onto the residue from the first step. After shaking the mixture for $16 \mathrm{~h}$ at room temperature, it was centrifuged for $15 \mathrm{~min}$, and then decanted into a beaker. Using $20 \mathrm{~cm}^{3}$ of deionized water, the residue was washed, centrifuged, and the supernatant discarded.

iii. Metals bound to organic matter and sulphides (Fraction III): $10 \mathrm{~cm}^{3}$ of $8.8 \mathrm{~mol} \mathrm{dm}^{-3}$ of hydrogen peroxide was carefully added in small aliquots to the residue in the centrifuge tube. The tube ingredients were digested at room temperature for $1 \mathrm{~h}$ with occasional manual shaking. The procedure was continued for $1 \mathrm{~h}$ at $85^{\circ} \mathrm{C}$ and the volume reduced to a few millilitres by further heating in a water bath. A second aliquot of $10 \mathrm{~cm}^{3}$ of hydrogen peroxide was added to the residue and the digestion procedure was repeated. The solution was heated to near dryness, and $50 \mathrm{~cm}^{3}$ of $1.0 \mathrm{~mol} \mathrm{dm}^{-3}$ ammonium acetate solution adjusted to $\mathrm{pH} 2.0$ with nitric acid) was added to the moist residue. The sample solution was shaken and centrifuged, and the extract was separated as described above.

iv. Residual (Fraction IV): The analysis of the residue was performed using aqua regia $(65 \% \mathrm{v} / \mathrm{v} \mathrm{HCl}+35 \% \mathrm{v} / \mathrm{v}$ $\mathrm{HNO}_{3}$ ) for metals insoluble in the previous steps. For this purpose, first, $6 \mathrm{~cm}^{3}$ of double-distilled water and then aqua regia solution in a sequence of 15 and $10 \mathrm{~cm}^{3}$ were added to the remaining residue. After adding each aqua regia solution, the residue was evaporated to near dryness on a water bath. The extract was filtered through filter paper by adding $1.0 \mathrm{~mol} \mathrm{dm}-3 \mathrm{HNO}_{3}$ solution in small amounts on the last residue in the centrifuge tube. The tube walls were carefully washed with the same acid solution and then the dregs were collected in a beaker.

\section{ELEMENTAL ANALYSIS}

Digests of soil samples were analyzed by Flame Atomic Absorption Spectrometer (BUCK SCIENTIFIC MODEL 210) for the concentrations of $\mathrm{Cu}, \mathrm{Pb}, \mathrm{Cr}, \mathrm{Cd}$ and $\mathrm{Zn}$. Also, elemental analysis was conducted for standard solutions prepared. The wavelengths of the machine used for $\mathrm{Cu}, \mathrm{Zn}, \mathrm{Cr}, \mathrm{Pb}$ and $\mathrm{Cd}$ were $324.7,213.9,357.9,283.3$ and $228.8 \mathrm{~nm}$ respectively.

\section{STATISTICAL ANALYSIS}

Descriptive statistical analysis and Pearson's correlation coefficients were employed to analyze data obtained for soil in study and control areas.

\section{QUALITY ASSURANCE/ RECOVERY STUDIES}

Quality control test was conducted on soil samples in order to evaluate the efficiency of Atomic Absorption Spectrometer. The spectrometer was calibrated according to manufacturer's recommendations. An acid blank and $10 \mathrm{mg} / \mathrm{cm}^{3}$ multi-element metal standard solution was used. Standards were analyzed for soil samples. The digests of soil samples were spiked with the multi-element metal standard solution and the recovery measurement determined by subtracting the metal concentration in the unspiked portion of the sample from the spiked portion [19].

\section{Results}

The results obtained from the recovery studies show that all the elements have more than $80 \%$ recovery as presented in Table 1. This indicated that all the procedures employed with respect to sample preparation and instrumentation gave reproducible results for the research work. The percentage recoveries were acceptable recoveries which validate the efficiency of the Atomic Absorption Spectrometer.

Table 1. Mean Percentage (\%) recoveries of soil samples.

\begin{tabular}{|l|l|l|l|l|l|}
\hline & $\mathrm{Cu}$ & $\mathrm{Zn}$ & $\mathrm{Cr}$ & $\mathrm{Pb}$ & $\mathrm{Cd}$ \\
\hline Soil & 84.10 & 92.00 & 88.00 & 93.20 & 88.10 \\
\hline
\end{tabular}

All the trace elements studied (i.e. $\mathrm{Cu}, \mathrm{Zn}, \mathrm{Cr}, \mathrm{Pb}$ and $\mathrm{Cd}$ ) were observed to be present in the soils of study area and control area. Table 2 shows the concentrations of the trace elements in sequential extraction fractions (I, II, III and IV) in soils of study area. The mobile components are fractions I and II. Table 3 shows the total concentrations (per sample) of the trace elements in soils of study area. Table 4 shows the concentrations of the trace elements in sequential extraction fractions (I, II, III and IV) in soils of control area and Table 5 shows the total concentrations (per sample) of the trace elements in soils of control area. Table 6 shows the descriptive statistics of the total concentrations of the trace elements in soils of both study area and control area. 
Bioavailable Trace Elements In Soils Around Nnpc Oil Depot Jos, Nigeria

Table 2: Concentrations of trace elements in sequential extraction fractions (I, II, III and IV) in soils of study area.

\begin{tabular}{|c|c|c|c|c|c|}
\hline \multicolumn{6}{|l|}{ Fraction I (mobile) } \\
\hline Sample & $\mathbf{C u}$ & $\mathbf{Z n}$ & $\mathrm{Cr}$ & $\mathbf{P b}$ & Cd \\
\hline 1 & 5.28 & 7.38 & 5.81 & 3.70 & 2.04 \\
\hline 2 & 4.69 & 4.81 & 0.55 & 1.44 & 2.30 \\
\hline 3 & 1.03 & 4.94 & 1.67 & 2.50 & 2.27 \\
\hline 4 & 1.27 & 4.42 & 1.89 & 2.34 & 2.09 \\
\hline 5 & 3.39 & 2.88 & 1.89 & 0.69 & 2.83 \\
\hline 6 & 4.34 & 2.62 & 3.68 & 0.23 & 2.63 \\
\hline 7 & 1.98 & 3.14 & 6.59 & 2.34 & 2.88 \\
\hline 8 & 2.57 & 2.24 & 1.11 & 0.99 & 2.52 \\
\hline 9 & 6.70 & 6.22 & 0.77 & 2.34 & 1.97 \\
\hline 10 & 1.62 & 4.17 & 0.55 & 1.94 & 1.94 \\
\hline Mean & 3.29 & 4.28 & 2.45 & 1.85 & 2.35 \\
\hline \multicolumn{6}{|l|}{ Fraction II (Mobile) } \\
\hline 1 & 4.10 & 9.30 & 5.58 & 3.70 & 2.27 \\
\hline 2 & 9.29 & 7.63 & 2.23 & 4.00 & 2.65 \\
\hline 3 & 9.65 & 8.28 & 4.58 & 4.46 & 2.45 \\
\hline 4 & 6.93 & 6.86 & 2.00 & 1.44 & 2.15 \\
\hline 5 & 4.93 & 12.64 & 0.43 & 3.55 & 2.07 \\
\hline 6 & 12.83 & 8.28 & 0.32 & 8.04 & 2.04 \\
\hline 7 & 3.28 & 4.55 & 1.33 & 2.80 & 2.04 \\
\hline 8 & 7.76 & 5.45 & 0.66 & 5.36 & 2.08 \\
\hline 9 & 9.65 & 6.09 & 5.03 & 6.42 & 1.87 \\
\hline 10 & 5.40 & 7.38 & 0.32 & 3.16 & 3.16 \\
\hline Mean & 7.38 & 7.65 & 2.25 & 4.30 & 2.28 \\
\hline $\begin{array}{l}\text { Mobile component } \\
\text { (I+II) }\end{array}$ & 10.67 & 11.93 & 4.70 & 6.15 & 4.62 \\
\hline \multicolumn{6}{|l|}{ Fraction III } \\
\hline 1 & 4.22 & 6.86 & 3.57 & 4.91 & 2.14 \\
\hline 2 & 8.58 & 6.73 & 2.78 & 7.77 & 2.01 \\
\hline 3 & 5.99 & 5.58 & 2.78 & 4.30 & 2.30 \\
\hline 4 & 5.28 & 7.12 & 3.57 & 6.87 & 2.42 \\
\hline 5 & 4.22 & 4.81 & 1.22 & 3.85 & 2.65 \\
\hline 6 & 2.69 & 5.96 & 11.41 & 4.15 & 2.25 \\
\hline 7 & 3.75 & 5.06 & 2.67 & 8.68 & 2.02 \\
\hline 8 & 6.22 & 8.15 & 2.45 & 6.87 & 2.90 \\
\hline 9 & 2.33 & 3.91 & 0.55 & 3.70 & 2.37 \\
\hline 10 & 0.45 & 5.19 & 5.92 & 1.94 & 1.94 \\
\hline Mean & 4.37 & 5.94 & 3.69 & 5.30 & 2.30 \\
\hline \multicolumn{6}{|l|}{ Fraction IV } \\
\hline 1 & 4.34 & 5.84 & 3.68 & 0.38 & 3.13 \\
\hline 2 & 3.39 & 5.96 & 3.79 & 0.84 & 1.97 \\
\hline 3 & 10.00 & 7.12 & 3.79 & 2.04 & 2.02 \\
\hline 4 & 14.13 & 7.12 & 8.61 & 4.15 & 1.89 \\
\hline 5 & 3.87 & 5.06 & 0.43 & 2.95 & 1.92 \\
\hline 6 & 2.10 & 6.61 & 3.90 & 2.34 & 2.25 \\
\hline 7 & 6.81 & 8.53 & 0.77 & 0.84 & 2.20 \\
\hline 8 & 5.52 & 9.05 & 7.15 & 9.58 & 2.65 \\
\hline 9 & 3.98 & 10.33 & 6.59 & 1.74 & 1.94 \\
\hline 10 & 16.84 & 6.35 & 1.55 & 1.92 & 1.92 \\
\hline Mean & 7.10 & 7.20 & 4.03 & 2.68 & 2.19 \\
\hline pH & \multicolumn{5}{|l|}{5.46} \\
\hline
\end{tabular}


Table 3: Total concentrations (per sample) of the trace elements in soils of study area

\begin{tabular}{|l|l|l|l|l|l|}
\hline \multicolumn{6}{|c|}{ Concentrations of Elements in Samples 1-10 } \\
\hline Samples & $\mathbf{C u}$ & $\mathbf{Z n}$ & $\mathbf{C r}$ & $\mathbf{P b}$ & $\mathbf{C d}$ \\
\hline 1 & 17.94 & 29.38 & 18.64 & 12.69 & 9.59 \\
\hline 2 & 25.96 & 25.14 & 9.35 & 14.05 & 8.93 \\
\hline 3 & 26.67 & 25.91 & 12.82 & 13.30 & 9.03 \\
\hline 4 & 27.61 & 25.53 & 16.06 & 14.80 & 8.55 \\
\hline 5 & 16.41 & 25.40 & 3.97 & 11.04 & 9.46 \\
\hline 6 & 21.95 & 23.47 & 19.31 & 14.80 & 9.16 \\
\hline 7 & 15.82 & 21.29 & 11.36 & 14.65 & 9.13 \\
\hline 8 & 22.07 & 24.88 & 11.36 & 22.80 & 10.16 \\
\hline 9 & 22.66 & 26.55 & 12.93 & 14.20 & 8.15 \\
\hline 10 & 24.32 & 23.08 & 8.34 & 8.96 & 8.96 \\
\hline
\end{tabular}

Table 4: Concentrations of trace elements in sequential extraction fractions (I, II, III and IV) in soils of control area

\begin{tabular}{|c|c|c|c|c|c|}
\hline \multicolumn{6}{|l|}{ Fraction I (Mobile) } \\
\hline & $\mathrm{Cu}$ & $\mathbf{Z n}$ & $\mathrm{Cr}$ & $\mathbf{P b}$ & Cd \\
\hline 1 & 0.56 & 3.39 & 1.89 & 1.14 & 0.20 \\
\hline 2 & 4.10 & 5.58 & 2.42 & 0.38 & 0.23 \\
\hline 3 & 8.58 & 6.22 & 7.03 & 0.23 & 0.68 \\
\hline 4 & 3.11 & 4.00 & 3.07 & 0.30 & 0.21 \\
\hline 5 & 2.03 & 5.44 & 2.33 & 0.31 & 0.13 \\
\hline 6 & 4.99 & 5.43 & 4.00 & 0.51 & 0.23 \\
\hline Mean & 3.90 & 5.01 & 3.46 & 0.48 & 0.28 \\
\hline \multicolumn{6}{|l|}{ Fraction II (Mobile) } \\
\hline 1 & 7.29 & 1.06 & 3.21 & 4.61 & 0.23 \\
\hline 2 & 3.75 & 8.15 & 0.44 & 3.10 & 0.23 \\
\hline 3 & 3.39 & 8.66 & 0.44 & 6.11 & 0.29 \\
\hline 4 & 2.91 & 4.23 & 1.31 & 2.79 & 0.30 \\
\hline 5 & 4.01 & 4.01 & 0.43 & 3.79 & 0.43 \\
\hline 6 & 3.11 & 5.89 & 0.67 & 6.00 & 0.21 \\
\hline Mean & 4.08 & 5.33 & 1.08 & 4.40 & 0.28 \\
\hline \multicolumn{6}{|l|}{ Fraction III } \\
\hline $\mathbf{1}$ & 4.85 & 6.86 & 0.71 & 1.59 & 0.26 \\
\hline 2 & 1.18 & 8.28 & 2.02 & 2.02 & 0.25 \\
\hline 3 & 3.39 & 8.79 & 2.29 & 5.66 & 0.21 \\
\hline 4 & 7.89 & 8.80 & 1.87 & 3.40 & 0.24 \\
\hline 5 & 6.54 & 4.33 & 1.00 & 5.99 & 0.19 \\
\hline 6 & 8.90 & 5.11 & 2.31 & 4.89 & 0.88 \\
\hline Mean & 5.46 & $\mathbf{7 . 0 3}$ & 1.70 & 3.92 & 0.34 \\
\hline \multicolumn{6}{|l|}{ Fraction IV } \\
\hline $\mathbf{1}$ & 5.75 & 1.01 & 1.63 & 3.85 & 0.25 \\
\hline 2 & 8.47 & 8.15 & 0.71 & 5.66 & 0.28 \\
\hline 3 & 1.34 & 1.17 & 0.71 & 6.72 & 0.21 \\
\hline 4 & 4.21 & 7.72 & 0.71 & 5.73 & 0.81 \\
\hline 5 & 9.00 & 8.44 & 0.44 & 2.28 & 0.21 \\
\hline 6 & 8.77 & 6.02 & 0.92 & 4.11 & 0.32 \\
\hline Mean & 6.26 & 5.42 & 0.85 & 4.73 & 0.35 \\
\hline Mobile component (I+II) & 7.97 & 10.34 & 4.54 & 4.88 & 0.56 \\
\hline pH & \multicolumn{5}{|l|}{5.62} \\
\hline
\end{tabular}


Table 5: Total concentrations (per sample) of the trace elements in soils of control area

\begin{tabular}{|l|l|l|l|l|l|}
\hline \multicolumn{6}{|c|}{ Concentration of Elements in samples } \\
\hline Sample & $\mathbf{C u}$ & $\mathbf{Z n}$ & $\mathbf{C r}$ & $\mathbf{P b}$ & $\mathbf{C d}$ \\
\hline 1 & 18.45 & 12.32 & 7.44 & 11.19 & 0.93 \\
\hline 2 & 17.49 & 30.15 & 5.59 & 11.16 & 0.99 \\
\hline 3 & 16.71 & 24.85 & 10.47 & 18.72 & 1.39 \\
\hline 4 & 18.13 & 24.75 & 6.97 & 12.22 & 1.56 \\
\hline 5 & 21.58 & 22.23 & 4.21 & 12.37 & 0.96 \\
\hline 6 & 25.77 & 22.46 & 7.89 & 15.51 & 1.64 \\
\hline
\end{tabular}

Table 6: Descriptive statistics of soil of study area and control area

\begin{tabular}{|c|c|c|c|c|c|c|c|c|c|c|}
\hline & $\begin{array}{l}\mathrm{Cu} \\
\text { (study) }\end{array}$ & $\begin{array}{l}\mathrm{Cu} \\
\text { (Control) }\end{array}$ & $\begin{array}{l}\mathrm{Zn} \\
\text { (study) }\end{array}$ & $\begin{array}{l}\mathrm{Zn} \\
\text { (Control } \\
\text { ) }\end{array}$ & $\begin{array}{l}\text { Cr (study } \\
\text { ) }\end{array}$ & $\begin{array}{l}\mathrm{Cr} \\
\text { (Control } \\
\text { ) }\end{array}$ & $\begin{array}{l}\mathrm{Pb} \text { (study } \\
\text { ) }\end{array}$ & $\begin{array}{l}\mathrm{Pb} \\
\text { (Control } \\
\text { ) }\end{array}$ & Cd (study & $\begin{array}{l}\text { Cd } \\
\text { (Control } \\
\text { ) }\end{array}$ \\
\hline Mean & 22.14 & 19.69 & 25.06 & 22.79 & 12.41 & 7.09 & 14.13 & 13.53 & 9.11 & 1.24 \\
\hline Median & 22.36 & 18.29 & 25.27 & 23.60 & 12.09 & 7.20 & 14.13 & 12.29 & 9.08 & 1.19 \\
\hline $\begin{array}{l}\text { Standard } \\
\text { Deviation }\end{array}$ & 4.22 & 3.41 & 2.18 & 5.87 & 4.71 & 2.13 & 3.58 & 3.00 & 0.55 & 0.33 \\
\hline Minimum & 15.82 & 16.71 & 21.29 & 12.32 & 3.97 & 4.21 & 8.96 & 11.16 & 8.15 & 0.93 \\
\hline Maximum & 27.61 & 25.77 & 29.38 & 30.15 & 19.31 & 10.47 & 22.80 & 18.72 & 10.16 & 1.64 \\
\hline Sum & 221.37 & 118.12 & 250.62 & 136.75 & 124.14 & 42.56 & 141.29 & 81.17 & 91.12 & 7.47 \\
\hline Count & 10 & 6 & 10 & 6 & 10 & 6 & 10 & 6 & 10 & 6 \\
\hline $\begin{array}{l}\text { Confidence } \\
\text { Level }(95.0 \%) \\
\end{array}$ & 3.02 & 3.58 & 1.56 & 6.16 & 3.37 & 2.24 & 2.56 & 3.15 & 0.40 & 0.34 \\
\hline
\end{tabular}

\section{Discussion}

It was observed that the total concentrations of the trace elements as obtained from sequential extraction and residual fractions (i.e. I+II+III+IV) in study area were higher than those of control area. Copper $(\mathrm{Cu})$ was observed to have total concentrations of $22.14 \mathrm{mg} / \mathrm{kg}$ in study area and $19.69 \mathrm{mg} / \mathrm{kg}$ in control area. The bioavailable component of $\mathrm{Cu}$ observed in study area and control area were $48.19 \%$ and $40.49 \%$ of the total concentration of $\mathrm{Cu}$ respectively. The high value of $\mathrm{Cu}$ and its high mobile component in study area could be attributed to anthropogenic activities such as discharge of effluents into surrounding environment by the oil facility during turn-around maintenance, traffic of heavy-duty vehicles that lift oil at the depot, corrosion of feed pipelines and other alloys, oil leakages and spillage [20,21].

The concentration of $\mathrm{Cu}(22.14 \mathrm{mg} / \mathrm{kg})$ reported in this study is lower than $47.0 \mathrm{mg} / \mathrm{kg}$ reported by Fisseha et al. (2008)[22]; $61 \mathrm{mg} / \mathrm{kg}$ by Ndiokwere (1984)[23]; $27 \mathrm{mg} / \mathrm{kg}$ by Ward et al. (1977[24]); $29.7 \mathrm{mg} / \mathrm{kg}$ by Jaradat and Momani (1999)[25]; it is however higher than $2.78 \mathrm{mg} / \mathrm{kg}$ reported by Bai et al. (2008)[26]. The bioavailable component of $\mathrm{Cu}$ in study area (48.19\%) is lower than 6-72\% and $0.4-74.4 \%$ reported by Nastja, R. S. (2011)[3]; Lena and Gade (1997)[4] respectively, while the value is higher than $16 \%$ and 3-30\% reported by Yobouet et al. (2010)[5] and Erika-Andrea et al. (2005)27] respectively.

$\mathrm{Zn}$ in this study was observed to have total concentrations $(\mathrm{mg} / \mathrm{kg}$ dry weight) of 25.06 and 22.79 in study area and control area respectively. The bioavailable component of $\mathrm{Zn}$ observed in study area and control area were $47.61 \%$ and $45.37 \%$ of the total concentration of $\mathrm{Zn}$ respectively. The high value of $\mathrm{Zn}$ observed in the study area could be attributed to corrosion and leakage of feed pipelines and storage tanks, emissions from traffic of heavy duty vehicles that lift oil at the depot and discharge of effluents during turn-around maintenance. The level of $\mathrm{Zn}$ reported in study area is lower than $237.96 \mathrm{mg} / \mathrm{kg}$ reported by Okunola et al. (2007)[28]; 761 $\mathrm{mg} / \mathrm{kg}$ reported by Sitkol et al. (2004)[29] and higher than values reported by Mitsios et al. (2005)[30] which ranged between $0.03-5.5 \mathrm{mg} / \mathrm{kg}$. Srinivas et al. (2009)[31] also reported $\mathrm{Zn}$ concentration in industrial area as $49.7 \mathrm{mg} / \mathrm{kg}$ and $32.2 \mathrm{mg} / \mathrm{kg}$ in rural area (control), these values are higher than the concentration of Zn (25.06 $\mathrm{mg} / \mathrm{kg}$ ) in study area and $22.79 \mathrm{mg} / \mathrm{kg}$ in control area reported in present study. The bioavailable component of $\mathrm{Zn}$ in study area $(47.61 \%)$ is lower than $24-60 \%$ and $86 \%$ reported by Nastja, R. S. (2011)[3] and Yobouet et al. (2010) [5]respectively. The value is however higher than 2.4-44.2\%, 5-20\% and 33.35\% reported by Lena and Gade (1997)[4]; Erika-Andrea et al. (2005)[27] and Olayinka et al. (2011)[32] respectively.

Chromium concentrations were observed as $12.41 \mathrm{mg} / \mathrm{kg}$ and $7.09 \mathrm{mg} / \mathrm{kg}$ in study area and control area respectively. The bioavailable component of $\mathrm{Cr}$ observed in study area and control area were $37.87 \%$ and $64.03 \%$ of the total concentration of $\mathrm{Cr}$ respectively. The observed concentration of $\mathrm{Cr}$ in study area could be due to leakage of feed pipelines or storage tanks and spillage of oil which has been reported by Nwachukwu et al. (1995)[33] to still contain minute concentrations of transition metals including $\mathrm{Cr}$ after refining. Other reasons for the concentration in the study area could be due to corrosion of pipelines and storage reservoirs, 
emissions from exhaust of heavy-duty vehicles and discharge of effluents during turn-around maintenance. The concentration of $\mathrm{Cr}$ in present study is less than $29.75 \mathrm{mg} / \mathrm{kg}$ reported by Adelekan and Abegunde (2011)[34]; and $10-50 \mathrm{mg} / \mathrm{kg}$ by Adriano (2001)[35]. The bioavailable component of $\mathrm{Cr}$ in study area (37.87\%) is higher than $22.36 \%$ reported by Olayinka et al. (2011)[32].

Lead $(\mathrm{Pb})$ was observed to have concentration of $14.13 \mathrm{mg} / \mathrm{kg}$ in study area and $13.53 \mathrm{mg} / \mathrm{kg}$ in control area. The bioavailable component of $\mathrm{Pb}$ observed in study area and control area were $43.52 \%$ and $36.07 \%$ of the total concentration of $\mathrm{Pb}$ respectively. The observed level of $\mathrm{Pb}$ in study area and its higher mobile component could be attributed to automobile exhaust emissions around the oil depot as reported by Aribike (1996)[36]; Lagerwerff and Specht (1970)[37]; Grigalaviciene et al. (2005)[38] and Awode et al. (2008)[39]. It could also be due to leakage of leaded-gasoline into the surrounding as reported by Ademorati (1986)[40] and Nwachukwu et al. (1995)[33]. The concentration of $\mathrm{Pb}$ in both study and control areas are lower than $76.92 \mathrm{mg} / \mathrm{kg}, 15,100$ $\mathrm{mg} / \mathrm{kg}$ and $203 \mathrm{mg} / \mathrm{kg}$ reported by Okunola et al. (2007)[28]; Adelekan and Abegunde (2011)[34] and Sitkol et al. (2004)[29] respectively. Srinivas et al., (2009)[31] reported $47.8 \mathrm{mg} / \mathrm{kg}$ in industrial area which is higher than level of $\mathrm{Pb}$ reported in soil around NNPC depot in present study while $8.1 \mathrm{mg} / \mathrm{kg}$ reported in rural area (control) was observed to be higher than the level of $\mathrm{Pb}$ reported in control area of present study. The bioavailable component of $\mathrm{Pb}$ in study area (43.52\%) is lower than $18-56 \%$ and $70.44 \%$ reported by Nastja, $\mathrm{R}$. S. (2011)[3] and Olayinka et al. (2011)[32] respectively, and higher than $20 \%$ and $30 \%$ reported by ErikaAndrea et al. (2005)[27] and Yobouet et al. (2010)[5] respectively.

Cadmium $(\mathrm{Cd})$ was observed to have a higher concentration $(9.11 \mathrm{mg} / \mathrm{kg})$ in study area than in control area $(1.24 \mathrm{mg} / \mathrm{kg})$. The bioavailable component of Cd observed in study area and control area were $50.71 \%$ and $45.02 \%$ of the total concentration of $\mathrm{Cd}$ respectively. The observed high concentration in study area could be due to discharge of effluents into the surrounding environment during turn-around maintenance, spillage of lubricating oils, wear and tear of tyres of vehicles, emissions by heavy-duty vehicles that lift oil at the depot and particles from gasoline combustion. This agrees with other literature on higher $\mathrm{Cd}$ concentration in industrial areas than in control areas [41, 37, and 42]. Adelekan and Abegunde, (2011)[34] reported Cd concentration of $17.23 \mathrm{mg} / \mathrm{kg}$ which was higher than the concentrations of $\mathrm{Cd}$ in study area and control area reported in present study, however Cd concentrations in both study and control area in present study were observed to be higher than $0.75 \mathrm{mg} / \mathrm{kg}$ reported by Jaradat and Momani (1999)[25] and $0.88 \mathrm{mg} / \mathrm{kg}$ by Bai et al. (2008)[26]. Cadmium concentration of $2.11 \mathrm{mg} / \mathrm{kg}$ reported by Amusan et al. (2003)[43] was also observed to be lower than the concentration of the element in study area and higher than the concentration in control area of present study. The bioavailable component of $\mathrm{Cd}$ in study area (50.71\%) is lower than 50-66\% and 2.0-70\% reported by Nastja, R. S. (2011)[3]; Lena and Gade (1997)[4] respectively, and higher than $30 \%$ and $48 \%$ reported by Erika-Andrea et al. (2005)[27] and Yobouet et al. (2010)[5] respectively.

Trace elements exhibit mobility in exchangeable phase (Fraction I) and reducible phase (Fraction II). Fig. 2 shows the mobile components of the trace elements in both study area and control area.

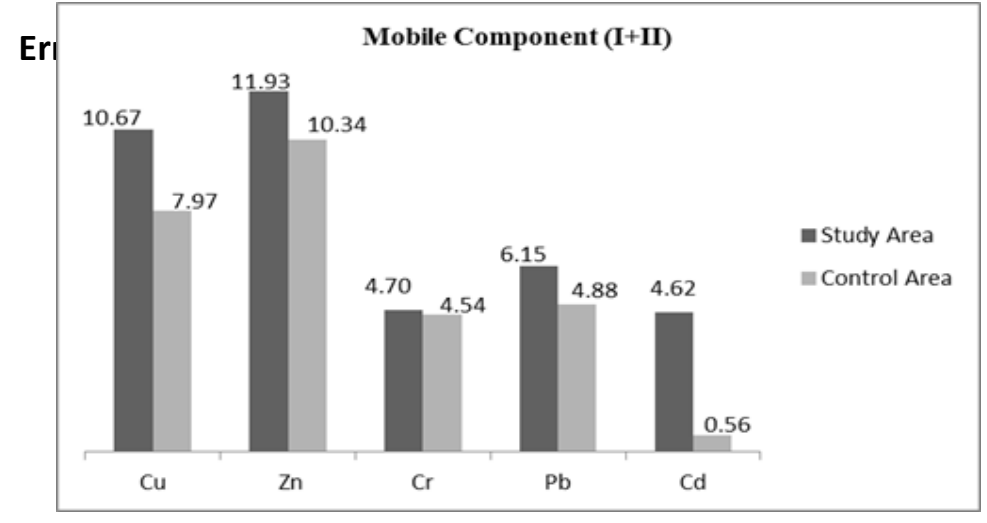

Fig. 2. Mobile Fractions (I+II) of soil in Study Area and Control Area.

It was observed that in exchangeable phase (Fraction I) and reducible phase (Fraction II), $\mathrm{Cu}$ and $\mathrm{Zn}$ exhibited highest mobility $(10.67 \mathrm{mg} / \mathrm{kg}$ and $11.93 \mathrm{mg} / \mathrm{kg}$ respectively) than $\mathrm{Cr}, \mathrm{Pb}$ and $\mathrm{Cd}(4.70 \mathrm{mg} / \mathrm{kg}, 6.15 \mathrm{mg} / \mathrm{kg}$ and $4.62 \mathrm{mg} / \mathrm{kg}$ respectively) in study area. In control area soils, $\mathrm{Cu}$ and $\mathrm{Zn}$ exhibited highest mobility $(7.97 \mathrm{mg} / \mathrm{kg}$ and $10.34 \mathrm{mg} / \mathrm{kg}$ respectively) than $\mathrm{Cr}, \mathrm{Pb}$ and $\mathrm{Cd}(4.54 \mathrm{mg} / \mathrm{kg}, 4.88 \mathrm{mg} / \mathrm{kg}$ and $0.56 \mathrm{mg} / \mathrm{kg}$ respectively). Hence, this suggests that $\mathrm{Cu}$ and $\mathrm{Zn}$ are more readily bioavailable in both study area and control soils. This agrees with the soil $\mathrm{pH}$ values (5.46 and 5.62) for study area and control area respectively as has been reported by McBride et al. (2004)[7] that $\mathrm{Cu}$ and $\mathrm{Zn}$ exhibit high extractability at low soil $\mathrm{pH}$ values than at high $\mathrm{pH}$ values (alkaline medium). 
The results in Tables 2 and 4 were subjected to linear regression analysis in order to find associations between all possible trace element pairs with a view to ascertaining whether they are from a common source. The Pearson's correlation coefficients obtained from the statistical computation are given in Table 7 (study area) and Table 8 (control area).

Table 7: Pearson's Correlation of Trace Element Pairs in soil of study area

\begin{tabular}{|l|l|l|l|l|l|}
\hline & $\mathrm{Cu}$ & $\mathrm{Zn}$ & $\mathrm{Cr}$ & $\mathrm{Pb}$ & $\mathrm{Cd}$ \\
\hline $\mathrm{Cu}$ & 1 & & & & \\
\hline $\mathrm{Zn}$ & 0.088182 & 1 & & & \\
\hline $\mathrm{Cr}$ & 0.163008 & 0.301888 & 1 & & \\
\hline $\mathrm{Pb}$ & 0.059827 & -0.02715 & 0.234974 & 1 & \\
\hline $\mathrm{Cd}$ & -0.43646 & 0.033218 & -0.09288 & 0.436641 & 1 \\
\hline
\end{tabular}

Table 8: Pearson's Correlation of Trace Element Pairs in soil of control area

\begin{tabular}{|l|l|l|l|l|l|}
\hline & $\mathrm{Cu}$ & $\mathrm{Zn}$ & $\mathrm{Cr}$ & $\mathrm{Pb}$ & $\mathrm{Cd}$ \\
\hline $\mathrm{Cu}$ & 1 & & & & \\
\hline $\mathrm{Zn}$ & -0.15437 & 1 & & & \\
\hline $\mathrm{Cr}$ & -0.20737 & -0.10542 & 1 & & \\
\hline $\mathrm{Pb}$ & 0.088836 & 0.172654 & 0.79305 & 1 & \\
\hline $\mathrm{Cd}$ & 0.341932 & 0.247415 & 0.539447 & 0.573294 & 1 \\
\hline
\end{tabular}

The Pearson's correlation coefficient values show that no significant correlation occurred between the trace element pairs in the soil of study area (Table 7). This suggests that all the trace elements are probably from different sources acting on the surroundings of the oil depot. These sources could be leakages from feed pipelines and storage facilities, exhaust emissions of fuel combustion by heavy duty vehicles that frequently lift oil at the depot, discharge of effluents into surrounding environment during turn-around maintenance and corrosion of storage facilities etc.

The correlation coefficient values for trace elements in control area (Table 8) were observed to be significant for $\mathrm{Cd}-\mathrm{Cr}$ and $\mathrm{Cd}-\mathrm{Pb}$ while for $\mathrm{Pb}-\mathrm{Cr}$ pair it was highly significant. This suggests that $\mathrm{Pb}$ and $\mathrm{Cr}$ are probably from the same source and this could be attributed to their primary natural mineral sources which when exposed to weathering releases the elements into the environment.

Generally, the concentrations of the trace elements in both study area and control area were observed to be within European Union (2002)[18] standards for permissible limits (mg/kg) of the trace elements in soils (135.00 for $\mathrm{Cu}, 300.00$ for $\mathrm{Zn}, 400.00$ for $\mathrm{Cr}, 300.00$ for $\mathrm{Pb}$ and 3.00 for $\mathrm{Cd}$ ) except for Cd concentration in study area which was observed to be higher than the permissible limit.

\section{Conclusion}

Speciation analyses give relevant information on the toxicity and biological activity of elements because the effects of these elements in soils do not depend on their concentrations alone, but also on their oxidation states and/or chemical forms. The results obtained from the sequential extraction analysis of soils collected around NNPC Oil depot Jos indicated that the concentrations of $\mathrm{Zn}, \mathrm{Cu}, \mathrm{Cr}$ and $\mathrm{Pb}$ were within permissible levels except for $\mathrm{Cd}$ which required attention.

Generally, the levels of trace elements in soils and their bioavailable components in the study area were observed to be lower than those of previous studies in industrial and residential areas and also lower than allowable limits by relevant standard organizations, this may be due partly to the controlled and cautious activity of the NNPC oil depot. However, it is important that the activities of the oil facility should be highly regulated to reduce the potential risks associated with the release of harmful trace elements into the surroundings. Also, periodic assessment of trace elements contents of soils and plants around the oil facility should be carried out.

\section{Acknowledgement}

This work was made possible with the assistance of Chemistry laboratories of Nigerian Defence Academy Kaduna, University of Jos and Kaduna State University, Nigeria. 
[1]. Wikipedia Encyclopedia (2009). www.wikipedia.org.

\section{References}

[2]. Tamunobereton-ari I., Omubo-pepple V. B. and Uko E. D. (2011). Heavy metal speciation in contaminated soils of an abandoned hydrocarbon exploration field camp and workshop site in parts of the Niger Delta, Nigeria. J. Basic Appl. Sci. Res., 1(6): 456-463.

[3]. Nastja Rogan Smuc (2011). Assessment of heavy metal contamination in paddy soils from Kocani field (Republic of Macedonia): Part II. Materials and Geoenvironment, vol. 58, no. 1: 47-58.

[4]. Lena Q. Ma and Gade N. Rao (1997). Chemical fractionation of Cadmium, Copper, Nickel and Zinc in contaminated soils. Journal of Environmental Quality. 26, no. 1: 259-264.

[5]. Yobouet Y. A., Adouby K., Trokourey A. and Yao B. (2010). Cadmium, Copper, Lead and Zinc speciation in contaminated soils. International Journal of Engineering Science and Technology. Vol. 2 (5): 802-812.

[6]. Christine Gleyzes, Sylvaine Tellier, Michel Astruc (2002). Fractionation studies of trace elements in contaminated soils and sediments: A review of sequential extraction procedures. J. of Trends in analytical chemistry, vol. 21, no. 6+7, pp. 451-467.

[7]. McBride M. B., Richards B. K. and Steenhuis T. (2004). Bioavailability and crop uptake of trace elements in soil columns amended with sewage sludge products. J. Plants and Soil. 262: 71-84.

[8]. Maina H. M., Egila J. N. And Shagal M. H. (2012). Chemical speciation of some heavy metals in sediments in the vicinity of Ashaka Cement Factory, Gombe state, Nigeria. Journal of Research in Environmental Science and Toxicology. Vol. 1 (7): 186-194.

[9]. Isidori M., Margherita L., Angela N. and Afredo P. (2003). Toxicity identification evaluation of leachates from municipal solid waste landfills: a multispecies approach chemosphere.www.elsevier.com/locate/chem.

[10]. United States Environmental Protection Agency (USEPA), 1992. Ground water issue: Behaviour of metals in soils. EPA/540/S92/018 October 1992.

[11]. Lindsay W. L. (1979). Chemical Equilibria in Soils. Wiley, New York. 162-209.

[12]. Serife T., Senol, K. and Gokhan B. (2003). Application of a three-stage sequential extraction procedure for the determination of extractable metal contents in Highway Soils. Turk. J. Chem. 27: 333-346.

[13]. Chaudri A. M., Allain C. M. G., Barbosa-Jefferson V. L., Nicholson F. A., Chambers B. J. and McGrath S. P. (2000). A study of the impacts of $\mathrm{Zn}$ and $\mathrm{Cu}$ on two rhizobial species in soils of a long-term field experiment. Plant Soil. 221: 167-179.

[14]. Knight B. P., Chaudri A. M., McGrath S. P. and Giller K. E. (1998). Determination of chemical availability of cadmium and zinc in soils using inert soil moisture samplers. Environ. Pollut. 99: 293-298.

[15]. Davis A., Ruby M. V. and Bergstrom P. D. (1994). Factors controlling lead bioavailability in the Butte mining district, Montana, USA: Environmental Geochemistry and Health. 3(4): 147-157.

[16]. McKinney J. and Rogers R. (1992). Metal bioavailability. Environmental Science and Technology. (26):1298-1299.

[17]. Nigeria Union of Petroleum and Natural Gas Workers (NUPENG), (2010). May Day Message. http://nupeng.org/id22.html

[18]. European Union (2002). Heavy Metals in Wastes. European Commission

[19]. Okoronkwo N. E., Odemelan S. A. and Ano O. A. (2006). Levels of toxic elements in soils of abandoned waste dump site. African Journal of Biotechnology. 5 (13): 1241- 1244

[20]. Turpeinen R. (2002). Interactions between metals, microbes and plants - Bioremediation of Arsenic and Lead contaminated soils. Ethesis.helsinki.fi/interact.pdf

[21]. Wong S. C., Li X. D., Zhang G., Qi S. H. And Min Y. S. (2002). Heavy metals in agricultural soils of the Pearl River Delta, South China. Environmental Pollution, 119: 33-44.

[22]. Fisseha I., Jorn B. and Mats O. (2008). The fate and bioavailability of some trace elements applied to two vegetable farms in Addis Ababa. African Journal of Agricultural Research. 3(11): 797-807.

[23]. Ndiokwere C. L. (1984). A study of heavy metal pollution from motor Vehicle emission and its effect on vegetation and crops in Nigeria. Environ. Pollut. (7): 35-42.

[24]. Ward N. I., Brook R. R., Roberts E. and Boswell C. (1977). Heavy metal pollution from automotive emissions and its effect on roadside soils and pasture species in New Zealand. Environ. Sci. Technol.11: 917-920.

[25]. Jaradat Q. M. and Momani K. A. (1999). Contamination of roadside soil, plants and air with heavy metals in Jordan, a comparative study. Turk. J. Chem. 23: 209-220.

[26]. Bai J., Cui B., Wang Q., Gao H. and Ding Q. (2008). Assessment of heavy metal contamination of roadside soils in Southwest China. Stoch. Environ. Res. Risk Ass. DOI 10.1007/s00477-008-0219-5.

[27]. Erika-Andrea Konradi, T. Frentiu, Michaela Ponta and E. Cordos (2005). Use of sequential Extraction to assess metal fractionation in soils from Bozanta Mare, Romania. Seria F. Chemia.8 :5-12.

[28]. Okunola O. J., Uzairu A. and Ndukwe G. (2007). Levels of trace metals in soil and vegetation along major and minor roads in metropolitan city of kaduna, Nigeria. African Journal of Biotechnology. 6(14):1703-1709.

[29]. Sitkol L. R., Zawisza B., Jurczyk J., Buhl F. and Zielonka U. (2004). Determination of High Zn and Pb Concentrations in Polluted Soils Using Energy-Dispersive X-ray Fluorescence Spectrometry. Polish Journal of Environmental Studies. 13(1):pp.91-96.

[30]. Mitsios I. K., Golia E. E. and Tsadilas C. D. (2005). Heavy Metal Concentrations in Soils and Irrigation Waters in Thessaly Region, Central Greece. Journal of Soil Science and Plant Analysis. 36 (4-6): 487-501.

[31]. Srinivas N., Ramakrishna R. S. and Suresh K. K. (2009). Trace Metal Accumulation in vegetables grown in industrial and semiurban areas- A case study. Applied Ecology and Environmental Research. 7(2):131-139.

[32]. Olayinka K. O., Oyeyiola A. O., Odujebe F. O. And Oboh B. (2011). Uptake of Potentially toxic metals by vegetable plants grown on contaminated soil and their potential bioavailability using sequential extraction. Journal of Soil Science and Environmental Management. Vol. 2 (8): 220-227.

[33]. Nwachukwu J. J., Oluwole A. F., Asubiojo O. I., Filby R. H., Grimm C. A. and Fitzgerald S. (1995). A geochemical evaluation of Niger Delta crude oils. In Geology of Deltas. Eds. N. O. Michael and George Postma. 287-300. Brookfield VT, USA.

[34]. Adelekan B. A. and Adegunde K. D. (2011). Heavy metals contamination of soil and groundwater at automobile mechanic villages in Ibadan, Nigeria. International Journal of the Physical Sciences. 6(5): 1045-1058. http//www.academicjournals.org

[35]. Adriano D. C. (2001). Trace elements in terrestrial environments. Biochemistry, Bioavailability and Risk of Metals. $2^{\text {nd }}$ Edition, Springer Verlag.

[36]. Aribike D. S. (1996). Environmental impacts of industrialization in Nigeria. A treatise paper presented at the conference of Nigerian Society of Chemical Engineers, November 14-16.

[37]. Lagerwerff J. V. and Specht A. W. (1970). Contamination of roadside soil and vegetation with cadmium, nickel, lead and zinc. J. Envir. Sci. Technol. 4: 583-586.

[38]. Grigalavičienė I., Rutkovienė V. and Marozas V. (2005). The accumulation of heavy metals Pb, Cu and Cd at Roadside Forest soil. Polish Journal of Environmental Studies .14(1): 109-115. 
[39]. Awode U. A., Uzairu A., Balarabe M. L, Okunola O. J. and Adewusi S. G. (2008). Levels of some trace metals in the fadama soils and pepper (Capsicum annuum) along the bank of river Challawa, Nigeria. Asian Journal of Scientific Resources.1:458-463.

[40]. Ademoroti C. M. A. (1986). Levels of heavy metals on bark and fruit trees in Benin-City, Nigeria. Int. J. Environ. Pollut. 11 : 241253.

[41]. Abechi E. S., Okunola O. J., Zubairu S. M., Usman A. A. and Apene E. (2010). Evaluation of heavy metals in roadside soils of major streets in Jos metropolis, Nigeria. Journal of Environmental Chemistry and Ecotoxicology. 2(6): 98-102.

[42]. Francek M. A. (1992). Soil lead levels in a small environment: a case study from Mt. pleasant, Michigan. J. Environ. Pollut. 76: 251-257.

[43]. Amusan A. A., Bada S. B. and Salami A.T. (2003). Effects of traffic density on heavy metal content of soil and vegetation along roadsides in Osun State, Nigeria. West Afr. J. App. Ecol. 4: 107-114. 